\title{
The accuracy of warfarin dosage based on VKORC1 and CYP2C9 phenotypes in a Chinese population
}

\author{
Agustinus Wijaya, ${ }^{1}$ Jiang T. Bo, ${ }^{1}$ He Jun, ${ }^{2}$ Jiang W. Ping, ${ }^{1}$ Jiang Bin, ${ }^{1}$ Chen H. Jie, ${ }^{2}$ Yang B. Wen, ${ }^{1}$ Xu M. Zhu, ${ }^{1}$ \\ Qiu Q. Cheng ${ }^{2}$ \\ ${ }^{1}$ Department of Cardiovascular Diseases, The First Affiliated Hospital of Soochow University, Suzhou, Jiangsu Province, China \\ ${ }^{2}$ Department of Haematology, The First Affiliated Hospital of Soochow University, Suzhou, Jiangsu Province, China
}

\begin{abstract}
Abstrak
Latar belakang: Penelitian ini bertujuan untuk menilai akurasi penentuan dosis warfarin berdasarkan genotip VKORC1 dan CYP2C9 pada populasi China.

Metode: Sebanyak 37 pasien diambil sampel darah. Dilakukan perbandingan antara dosis warfarin yang didapat dari genotip (merujuk pada www.warfarindosing.org) dengan dosis terapi kadar INR 2,0 sampai 3,0.

Hasil: Majoritas penduduk China pada studi ini memiliki genotip VKORC1 AA homozigot (89,2\%), jarang ditemukan penduduk dengan VKORC1 AG heterozigot, dan tidak ditemukan pasien dengan GG homozigot. Untuk genotip CYP2C9, hampir seluruh pasien dengan variasi wildtype (CYP2C9*2 CC dan CYP2C9*3 AA). Dosis warfarin pada pasien dengan VKORC1 AA dan CYP2C9*3 AC lebih rendah daripada variasi genotip yang lain.

Kesimpulan: Tidak ada perbedaan yang signifikan antara dosis warfarin berdasarkan algoritma farmakogenetik dan dosis terapi kami. Dapat disimpulkan bahwa algoritma farmakogenetik akurat dalam menentukan dosis warfarin. (Med $\mathbf{J}$ Indones. 2012;21:108-12)
\end{abstract}

\begin{abstract}
Background: The aim of this study is to assess the accuracy of warfarin dosage based on VKORC1 and CYP2C9 genotype in Chinese population.

Methods: Blood samples were taken from 37 patients. We compared the warfarin dosage obtained from genotype (according to www.warfarindosing.org) and treatment dosage with international normalized ratio (INR) value within 2.0-3.0.

Results: The majority of Chinese people in our study are VKORC1 homozygous AA(89.2\%), rarely VKORC1 heterozygous AG and we cannot find a patient with homozygous GG. For CYP2C9 genotype, most patients have the wildtype variants (CYP2C9*2 CC and CYP2C9*3 AA). The warfarin dosage for patients with VKORC1 AA and CYP2C9*3 AC is lower than for patients with other genotype variants.

Conclusion: There is no significant difference between pharmacogenetic algorithm (www.warfarindosing.org) and our treatment dosage. Our conclusion is that the pharmacogenetic algorithm is accurate to predict the warfarin dose. (Med J Indones. 2012;21:108-12)
\end{abstract}

Keywords: CYP2C9, pharmacogenetic algorithm, VKORC1, warfarin

Warfarin, a coumadin derivative, is the mostly prescribed anticoagulant worldwide. In many cases, like atrial fibrillation, heart failure, cardiomyopathy, post open heart surgery, warfarin is used to prevent a thrombus. On other cases, warfarin is used as secondary prophylaxis when the patient already formed a thrombus, such as in deep vein thrombosis and pulmonary embolism. The anticoagulant effect of warfarin is produced by interference with the vitamin $\mathrm{K}$ cycle. Vitamin $\mathrm{K}$ is needed to modify certain proteins, which are required for blood coagulation. Glutamate residues, $\gamma$-carboxyglutamates (Gla) depend on vitamin $\mathrm{K}$ as a cofactor to carboxylation. Vitamin $\mathrm{K}$ dependent proteins including coagulation factors II, VII, IX and $\mathrm{X}$ require $\gamma$-carboxyglutamates to be activated. In the other hand, by interference with the vitamin $\mathrm{K}$ cycle, warfarin induces the production of decarboxylated proteins with reduced coagulant effect. ${ }^{1}$ Warfarin is metabolized by the hepatic enzyme cytochrome P450 responsible for its activity. VKORC1 and CYP2C9 are two important genes taking role of warfarin metabolism. VKORC1 (Vitamin K epoxide reductase complex subunit 1) is an enzyme that mediates the anticoagulant effect of warfarin. Warfarin inhibits this target enzyme. CYP2C9 is a gene that is responsible for the duration of warfarin biotransformation. Variation of the CYP2C9 gene can cause slow metabolism of warfarin. Thus, the patients have higher blood concentrations of warfarin because of its accumulation, and have a stronger anticoagulant effect. In summary, the sensitivity of warfarin is based on VKORC1 gene and the duration of warfarin metabolism is based on CYP2C9. Variation in either gene can increase the risk of bleeding during warfarin therapy. ${ }^{2-7}$ Warfarin has a narrow therapeutic window. The risk of thromboembolism recurrence rises in patients with international normalized ratio (INR) 
values below 2, but INR values exceeding 3 and in particular above 4 , greatly increase the risk of bleeding. Response to warfarin varies greatly among individuals, so that some patients may require less than $1 \mathrm{mg}$ daily, whereas others may need more than $20 \mathrm{mg}$ per day to achieve similar anticoagulation..$^{8-10}$

A number of warfarin dosing algorithms and computergenerated dosing regimens have been developed to reduce the risk of over-anticoagulation during therapy. Nowadays, the use of genetic tests may reduce the time to achieve stable doses and blood levels.

\section{METHODS}

\section{Patient population}

This study was approved by the Health Authority Ethics Committee of The First Affiliated Hospital of Soochow University. This study involved 37 patients with following inclusion criteria: patients were admitted to the Cardiovascular Department, received warfarin therapy and got their blood checked for VKORC1 and CYP2C9 genes. Exclusion criteria for our study were patients who received warfarin therapy but did not get a related gene check, patients with abnormal hepatic and renal function based on blood test. Patients' characteristics such as gender, age, height, weight, smoking history, drugs that can affect the warfarin metabolism were recorded during our research. Patients' age data was taken from their IDs or from a person who could provide this information. Height and weight were measured when patients were admitted to our department. Smoking history was noted based on our interview with the patient. Drugs that can effect warfarin metabolism include: aspirin, non steroidal anti-inflammatory drugs (NSAIDS), antibiotics like penicillin in high dosage and derivates of penicillin, amiodarone, any azole (e.g. Fluconazole), sulfamethoxazole/ bactrim/ septra/ coatrim/ sulfatrim, cholesterol lowering agents etc. All participants of this study were followed up after they achieved stable therapeutic dose of warfarin for 2-3 consecutive visits.

\section{International normalized ratio}

The measurement of patients' INR was carried out by the Clinical Laboratory Department of Soochow University.

\section{Genotyping}

Blood samples were collected from patients, about 4 $\mathrm{mL}$ in tubes containing EDTA. We extracted the DNA with Wizard Genomic DNA purification kit (Promega). DNA was stored at $2-8^{\circ} \mathrm{C}$. Then, DNA was amplified by PCR. The PCR was carried out in a Bio-Rad DNA thermal cycler (Hercules, CA) with an initial denaturation of 10 minutes at $95^{\circ} \mathrm{C}$, followed by 30 cycles of denaturation at $95^{\circ} \mathrm{C}$ for 30 seconds, annealing at $56^{\circ} \mathrm{C}$ for 30 seconds, extension at $72^{\circ} \mathrm{C}$ for 1 minute, and final extension at $72^{\circ} \mathrm{C}$ for 7 minutes. For gene sequencing, we used the sequence based typing (SBT) method. ABI 3730 PCR products detect the VKORC1 $(-1639 \mathrm{G}>\mathrm{A})$, CYP2C $9 * 2$ and CYP2C9*3 loci.

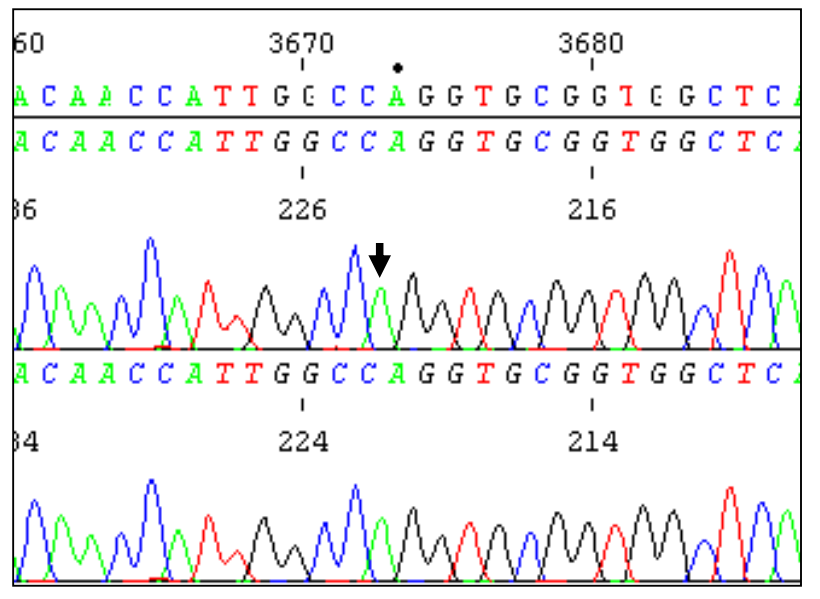

Figure 1. VKORC1 AA sequence

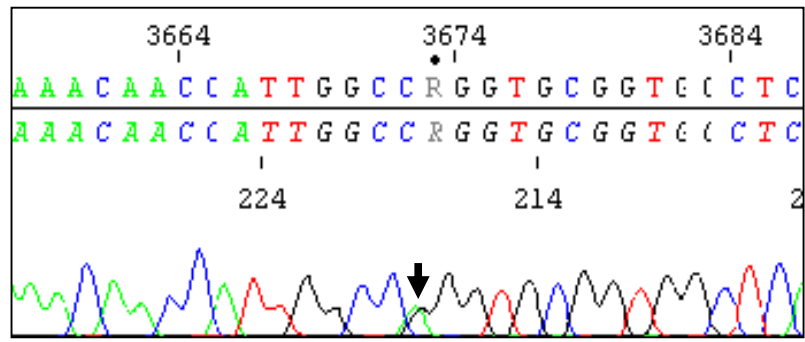

Figure 2. VKORC1 AG sequence

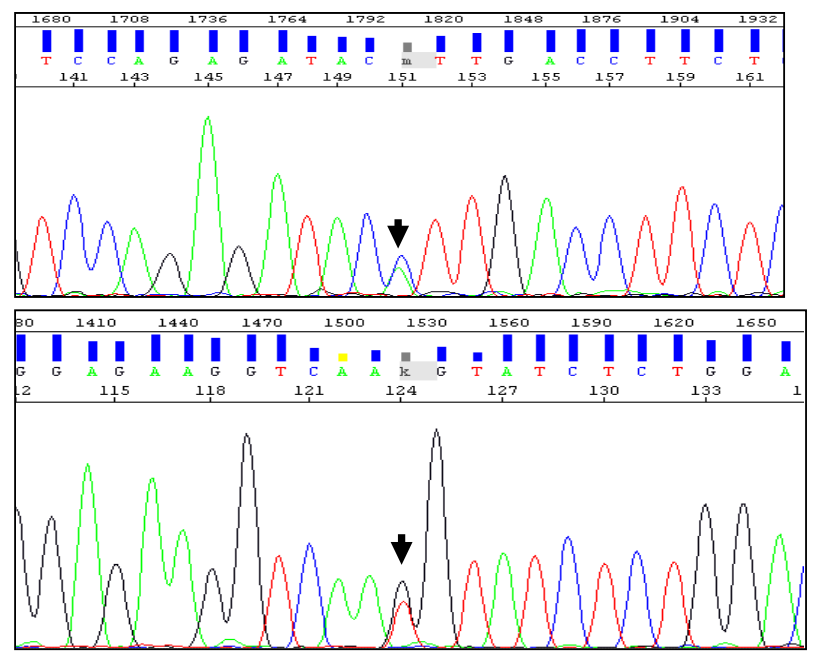

Figure 3. $\mathrm{CYP} 2 \mathrm{C} 9 * 3$ 


\section{Estimated therapeutic dose}

Individual patient's drug doses were estimated according to the pharmacogenetic algorithm available at www. warfarindosing.org. Factors included in this algorithm are VKORC1 and CYP2C9 genotypes, age, gender, body weight, body height, target INR, amiodarone use, smoking status, and warfarin indication.

\section{Stable therapeutic dose}

Stable therapeutic dose indicates warfarin dosage per day taken by patients with INR values $2.0-3.0$, which were stabilized for 3-4 consecutive visits.

\section{Data analysis}

Data analyses were performed by using the Special Package for Social Science (SpSS version 15.0, SPSS Science, Chicago, IL). Because this is a matched data set, we used non parametric Wilcoxon test for the comparison between the estimated therapeutic dose and stable therapeutic dose.

\section{RESULTS}

All 37 patients consented to take part in this study. The patients' characteristics, genotype, and warfarin indication therapy are shown in table 1 .

From 37 patients, twenty three male patients $(62.2 \%)$ and 14 female patients (37.8\%), the majority of warfarin indication was for atrial fibrillation $(70.3 \%)$, one case for cardiomyopathy, and 2 for other cases (aneurysm of femoral vein and after prosthetic heart valve surgery). For VKORC1 (-1639G > A) allelic variation, thirty-three patients were homozygous AA (sensitive), four patients were heterozygous $\mathrm{AG}$, and no patient had insensitive homozygous GG. Patients with VKORC1 genotype AG need higher doses of warfarin $(4.38 \pm 1.30 \mathrm{mg})$ than patients with genotype AA $(2.32 \pm 0.89 \mathrm{mg})$ (Table 2$)$.

For CYP2C9*2, all patients were homozygous CC (wild type), which need $2.54 \pm 1.13 \mathrm{mg}$ warfarin dose. For CYP2C $9 * 3$ genotype, three patients $(8.1 \%)$ were heterozygous $\mathrm{AC}$, and the other patients $(91.9 \%)$ were homozygous AA (wild type). Variation of CYP2C9 gene causes some patients to have slow metabolism of warfarin and a longer half-life of the drug. Significantly, patients with CYP2C9*3 AC variation need lower dose than with AA variation.

Based on our study, non-parametric Wilcoxon test result was a two-tailed $\mathrm{P}$ value of $0.06(\mathrm{p}>0.05)$. Therefore, our conclusion is that there was no significant difference between estimated therapeutic dose and the warfarin stable dose that we applied to the patients in our ward. The pharmacogenetic algorithm (www.warfarindosing.org) can predict or estimate the therapeutic dose of warfarin.

Table 1. Characteristics of study population

\begin{tabular}{ll}
\hline Variable & Patients $(\mathrm{n}=37)$ \\
\hline Gender [n(\%)] & $23(62.2)$ \\
Male & $14(37.8)$ \\
Female & \\
Age, in years [median (range)] & $68(26-86)$ \\
Male & $70(36-78)$ \\
Female & \\
Smoking History [n(\%)] & $14(37.8)$ \\
Yes & $23(62.2)$ \\
No & \\
Warfarin indication [n(\%)] & $26(70.3)$ \\
AF & $8(21.6)$ \\
DVT/PE & $1(2.7)$ \\
HF/Cardiomyopathy & $2(5.4)$ \\
Other & \\
VKORC1 genotype [n(\%)] & $0(0)$ \\
GG & $4(10.8)$ \\
AG & $33(89.2)$ \\
AA & \\
CYP2C9*2 genotype [n(\%)] & $37(100)$ \\
CC & $0(0)$ \\
CT & $0(0)$ \\
TT & $34(91.9)$ \\
CYP2C9*3 genotype [n(\%)] & $0(0)$ \\
AA & \\
AC & \\
CC & \\
\hline AF:Atral Fibrillation, DVT: Deep Vein \\
(n)
\end{tabular}

AF: Atrial Fibrillation, DVT: Deep Vein Thrombosis, PE: Pulmonary Embolism, HF: Heart Failure

Table 2. Clinical characteristics of patients by VKORC1 genotype

\begin{tabular}{lll}
\hline \multicolumn{1}{c}{ Characteristics } & \multicolumn{1}{c}{ VKORC1 AG } & \multicolumn{1}{c}{ VKORC1 AA } \\
\hline Mean age, in years \pm SD (range) & $56.75 \pm 15.09(37-72)$ & $67.33 \pm 13.95(26-86)$ \\
Mean weight, in $\mathrm{kg} \pm \mathrm{SD}$ & $78.25 \pm 15.50$ & $65.48 \pm 10.72$ \\
Mean height, in cm $\pm \mathrm{SD}$ & $167.00 \pm 9.42$ & $166.27 \pm 7.09$ \\
Mean estimated dose, in $\mathrm{mg} \pm \mathrm{SD}$ & $4.75 \pm 0.70$ & $2.46 \pm 0.72$ \\
Mean stable warfarin dose, in $\mathrm{mg} \pm \mathrm{SD}$ & $4.38 \pm 1.30$ & $2.32 \pm 0.89$ \\
\hline
\end{tabular}


Table 3. Clinical characteristics of patients by CYPC29*2 and CYP2C9*3

\begin{tabular}{llll}
\hline \multicolumn{1}{c}{ Characteristics } & CYP2C9*2 CC & \multicolumn{1}{c}{ CYP2C9*3 AA } & CYP2C9*3 AC \\
\hline Mean age, in years \pm SD (range) & $66.19 \pm 14.25$ & $66.91 \pm 12.94$ & $58.00 \pm 28.00$ \\
& $(26-86)$ & $(36-86)$ & $(26-78)$ \\
Mean weight, in $\mathrm{kg} \pm \mathrm{SD}$ & $66.86 \pm 11.76$ & $66.65 \pm 11.85$ & $69.33 \pm 12.74$ \\
Mean height, in $\mathrm{cm} \pm \mathrm{SD}$ & $166.35 \pm 7.22$ & $166.35 \pm 7.12$ & $166.33 \pm 10.02$ \\
Mean estimated dose, in $\mathrm{mg} \pm \mathrm{SD}$ & $2.71 \pm 1.01$ & $2.78 \pm 1.04$ & $1.97 \pm 0.72$ \\
Mean stable warfarin dose, in $\mathrm{mg} \pm \mathrm{SD}$ & $2.54 \pm 1.13$ & $2.68 \pm 1.05$ & $0.88 \pm 0.32$
\end{tabular}

\section{DISCUSSION}

Four years ago, the U.S. Food and Drug Administration updated the warfarin (Coumadin, Bristol-Myers Squibb, Princeton, NJ) product label to add pharmacogenetic information. ${ }^{11}$ Last year, the agency added specific instructions on how to use genotype to predict individualized doses: the new label provides a concise table of dosing recommendations, stratified by genotype. ${ }^{12}$ In contrast, most research on pharmacogenetic warfarin dosing has focused on developing and validating complex predictive algorithms, ${ }^{13,14}$ which integrate clinical and genetic factors to predict dose on the basis of regression equations. Recent research on warfarin dose prediction has focused on the use of pharmacogenetic algorithms. VKORC1 and CYP2C9 were the main genes that effect the warfarin dose and metabolism in human body. Our study focus on the accurate warfarin dose is based on these genes. In Chinese population, especially in our study $(\mathrm{n}=37)$, we couldn't find a patient with VKORC1 GG allele. Two patients had AG allele and other patients AA genotype. In an earlier study, Miao et $\mathrm{al}^{15}$ with large population $(n=178)$, found only one patient with VKORC1 GG, 49 patients with AG, and 149 patients with AA genotype. Therefore, we could make a conclusion that Chinese population mostly carries VKORC1 AA. Patients with VKORC1 AA need a lower dose of warfarin. For CYP2C $9 * 2$ genotype, all of our study population had $\mathrm{CC}$ allele and for $\mathrm{CYP} 2 \mathrm{C} 9 * 3$ genotype, the majority had AA allele, a few AC, and no one CC allele. CYP2C9*3 $\mathrm{AC}$ needs lower dose of warfarin $(0.88 \pm 0.32 \mathrm{mg})$ than AA allele $(2.68 \pm 1.05 \mathrm{mg})$.

In our study, dosing based on pharmacogenetic algorithm was accurate to predict the dose that patients needed to reach INR values within 2.0-3.0. Nonetheless, even with the pharmacogenetic algorithm, some patients were not dosed accurately. There are several reasons; first, clinical factors other than those included in our study (like tumor disease, antibiotic, dietary) can affect warfarin dose. ${ }^{16-19}$ Second, genes other than CYP2C9 and VKORC1 may affect warfarin dose, such as CYP4F2, GGCX, EPHX1, and ApoE, ${ }^{18,20-22}$ although their effects on warfarin dose require confirmation. ${ }^{23-25}$ These and other genes could be incorporated into future pharmacogenetic algorithms or tables to improve their accuracy; however, studies are needed to assess their clinical utility. ${ }^{26}$

The cost of warfarin-related genetic testing is 800 RMB in our hospital. Hopefully, this cost will fall in the future. Thereby, the genotype testing will become a routine test for the patient, and make a step forward in warfarin dosing. Although the pharmacogenetic algorithm can estimate the warfarin dose, it remains unknown whether using this algorithm can improve laboratory or clinic. On the other hand, we still need a lot of observational studies and further research.

\section{REFERENCES}

1. Hirsh J, Fuster V, Ansell J, Halperin JL, American Heart Association/American College of Cardiology Foundation. American Heart Association/American College of Cardiology Foundation guide to warfarin therapy. J Am Coll Cardiol. 2003;41(9):1633-52.

2. Friberg L, Hammar N, Ringh M, Petterson H, Rosenqvist M. Stroke prophylaxis in atrial fibrillation: who gets it and who does not? Report from the Stockholm Cohortstudy on Atrial Fibrillation (SCAF-study). Eur Heart J. 2006;27:1954-64.

3. McClain MR, Palomaki GE, Piper M, Haddow JE. A rapid ACCE review of CYP2C9 and VKORC1 allele testing to inform warfarin dosing in adults at elevated risk for thrombotic events to avoid serious bleeding [Internet]. Study commissioned by American College of Medical Genetics. 2006 Dec [updated 2007 Augt 20]. Available from: http://www.acmg.net

4. Rieder MJ, Reiner AP, Gage BF, Nickerson DA, Eby CS, McLeod HL, et al. Effect of VKORC1 haplotypes on transcriptional regulation and warfarin dose. N Engl J Med. 2005;352:2285-93.

5. Gage BF. Pharmacogenetic-based coumarin therapy. Hematology Am Soc Hematol Educ Program. 2006;2006:467-73.

6. Yuan HY, Chen JJ, Lee MT, Wung JC, Chen YF, Charng $\mathrm{MJ}$, et al. A novel functional VKORC1 promoter polymorphism is associated with inter-individual and interethnic differences in warfarin sensitivity. Hum Mol Genet. 2005; 14:1745-51. 
7. Sconce EA, Khan TI, Wynne HA, Avery P, Monkhouse L, King BP, et al. The impact of CYP2C9 and VKORC1 genetic polymorphism and patient characteristics upon warfarin dose requirements: proposal for a new dosing regimen. Blood. 2005;106:2329-33.

8. Quteineh L, Verstuyft C, Descot C, Dubert L, Robert A, Jaillon P, et al. Vitamin K epoxide reductase (VKORC1) genetic polymorphism is associated to oral anticoagulant overdose. Thromb Haemost. 2005;94:690-1.

9. Limdi NA, McGwin G, Goldstein JA, Beasley TM, Arnett $\mathrm{DK}$, Adler BK, et al. Influence of CYP2C9 and VKORC1 $1173 \mathrm{C} / \mathrm{T}$ genotype on the risk of hemorrhagic complications in African-American and European-American patients on warfarin. Clin Pharmacol Ther. 2008;83:312-21.

10. Caraco Y, Blatnick S, Muszkat M. CYP2C9 genotypeguided warfarin prescribing enhances the efficacy and safety of anticoagulation: a prospective randomized controlled study. Clin Pharmacol Ther. 2008;83:460-70.

11. Gage BF, Lesko LJ. Pharmacogenetics of warfarin: regulatory, scientific, and clinical issues. $\mathrm{J}$ Thromb Thrombolysis. 2008;25:45-51.

12. Brisotol-Meyers Squibb Company [Internet]. Coumadin ${ }^{\circledR}$ tablets (warfarin sodiumtablets, USP) crystalline; Coumadin $\AA$ for injection (warfarin sodium for injection, USP). [cited 2010 Feb 2]. Available from: http://www.accessdata.fda.gov/ drugsatfda docs/ label/2010/009218s108lbl.pdf

13. Gage BF, Eby C, Johnson JA, Deych E, Rieder MJ, Ridker $\mathrm{PM}$, et al. Use of pharmacogenetic and clinical factors to predict the therapeutic dose of warfarin. Clin Pharmacol Ther. 2008;84:326-31.

14. Klein TE, Altman RB, Eriksson N, Gage BF, Kimmel SE, Lee MT, et al. Estimation of the warfarin dose with clinical and pharmacogenetic data. N Engl J Med. 2009;360:753-64.

15. Miao L, Yang J, Huang C, Shen Z. Contribution of age, body weight, and CYP2C9 and VKORC1 genotype to the anticoagulant response to warfarin: proposal for a new dosing regimen in Chinese patients. Eur J Clin Pharmacol. 2007;63:1135-41.

16. Garcia D, Regan S, Crowther M, Hughes RA, Hylek EM. Warfarin maintenance dosing patterns in clinical practice: implications for safer anticoagulation in the elderly population. Chest. 2005;127:2049-56.
17. Gage BF, Eby C, Milligan PE, Banet GA, Duncan JR, McLeod HL. Use of pharmacogenetics and clinical factors to predict the maintenance dose of warfarin. Thromb Haemost. 2004;91:87-94.

18. Finkelman BS, Gage BF, Johnson JA, Brensinger CM, Kimmel SE. Genetic warfarin dosing: tables versus algorithms. J Am Coll Cardiol. 2011;57(5):612-8.

19. Absher R, Moore M, Parker M. Patient-specific factors predictive of warfarin dosage requirements. Ann Pharmacother. 2002;36:1512-7.

20. Kimmel S, Christie J, Kealey C, Chen Z, Price M, Thorn C, et al. Apolipoprotein E genotype and warfarin dosing among Caucasians and African Americans. Pharmacogenomics J. 2008;8:53-60.

21. Wells P, Majeed H, Kassem S, Langlois N, Gin B, Clermont $\mathrm{J}$, et al. A regression model to predict warfarin dose from clinical variables and polymorphisms in CYP2C9, CYP4F2, and VKORC1: derivation in a sample with predominantly a history of venous thromboembolism. Thromb Res. 2010;125:e259-64.

22. Kimura R, Miyashita K, Kokubo Y, Akaiwa Y, Otsubo $\mathrm{R}$, Nagatsuka $\mathrm{K}$, et al. Genotypes of vitamin $\mathrm{K}$ epoxide reductase, gamma-glutamyl carboxylase, and cytochrome P450 2C9 as determinants of daily warfarin dose in Japanese patients. Thromb Res. 2007;120:181-6.

23. Pautas E, Moreau C, Gouin-Thibault I, Golmard JL, Mahé I, Legendre C, et al. Genetic factors (VKORC1, CYP2C9, EPHX1, and CYP4F2) are predictor variables for warfarin response in very elderly, frail inpatients. Clin Pharmacol Ther. 2010;87:57-64.

24. Carlquist J, Horne B, Mower C, Park J, Huntinghouse J, McKinney $\mathrm{J}$, et al. An evaluation of nine genetic variants related to metabolism and mechanism of action of warfarin as applied to stable dose prediction. J Thromb Thrombolysis. 2010;30:358-64.

25. Lee MT, Chen CH, Chou CH, Lu LS, Chuang HP, Chen YT, et al. Genetic determinants of warfarin dosing in the HanChinese population. Pharmacogenomics. 2009;10:1905-13.

26. Cavallari L, Langaee T, Momary K, Shapiro N, Nutescu E, Coty W, et al. Genetic and clinical predictors of warfarin dose requirements in African Americans. Clin Pharmacol Ther. 2010;87:459-64. 